\title{
Paleozoogeography of the Wine Mouse (Akodon oenos) \& Late Holocene Paleoenvironments in South-Central Mendoza, Argentina
}

\author{
Fernando Julián Fernández
}

Author Address: CONICET. Cátedra de Anatomía Comparada, Facultad de Ciencias Naturales y Museo, Universidad Nacional de La Plata, Calle 64 s/n (entre diag. 113 y calle 120), La Plata, Argentina

fernandezf77@yahoo.com.ar

Received: November $24^{\text {th }} 2010$

Volume 1:52-57

Published: February $14^{\text {th }} 2011$

(C) 2010 Society of Ethnobiology

Abstract: Cranial remains of the wine mouse (Akodon oenos) are documented from an archaeological site in south-central Mendoza, Argentina (Agua de La Mula, 35022' S, 68015' W), which dates to the end of the late Holocene (1610 $\pm 60 ; 1260 \pm$ $60 ; 1000 \pm 50 C^{14}$ y B.P.). The taxonomic status of this small rodent is currently being assessed, but these remains represent the first fossil record for the morphotaxon A. oenos. The species' present distribution is restricted to a few records from Mendoza province. Analysis of the remains supports paleoenvironmental reconstruction using the small mammal assemblage recovered from this site. From the late Holocene into modernity temperature decreased and winter precipitation increased, resulting in advance of Patagonian steppe grading with altitude into Monte desert. Holocene climatic conditions may explain the relatively late human occupation of ecologically marginal environments in this region, which probably favored effective human occupation of the Payunia region at sites such as Agua de La Mula between 1600 and 1000 years B.P.

Key Words: Akodon oenos, paleoenvironmental analysis, Agua de la Mula, Mendoza, Argentina

\section{Introduction}

The wine mouse, Akodon oenos (Braun et al. 2000), is a poorly known small rodent of the family Cricetidae (subfamily Sigmodontinae, tribe Akondotini) for which no fossil remains have been reported. Knowledge about the biogeography of the species is restricted to a few records from Mendoza, Argentina. These records range from north-central arid environments of the Monte desert and Puna in localities that are modified by modern human activities (mainly wineyards and olive groves) to the southwest (see Figure 1A) in wetland habitat in the foothills of the volcanic Payunia region, which is in the semi-arid Patagonian steppe (Braun et al. 2000; Contreras and Rosi 1980; Pardiñas et al. 2011). Akodon oenos lives in sympatry with $A$. molinae, the only akodontines reported within Mendoza (Braun et al. 2000; Pardiñas et al. 2011). In general, knowledge of small mammal paleobiogeography and of Holocene paleoenvironmental conditions from the volcanic Payunia region of Mendoza is limited.

In this paper the first fossil record of the $A$. oenos from the Agua de La Mula archaeological site in southcentral Mendoza, Argentina is presented. In addition, the species' taxonomic status and geographic distribution are discussed. The paleobiogeography of $A$. oenos is integrated into reconstruction of environmental conditions during the late Holocene in the region via analysis of the small mammal assemblages from Agua de La Mula. This paleogeographic and paleoenvironmental study expands ongoing discussion of humanenvironment interactions during the very late Holocene in southern, central Mendoza.

\section{Study Area}

The Agua de La Mula site is located near the northern boundary of the volcanic Payunia region (Figure 1A). This area is within the Monte phytogeographic province (Cabrera 1976), which is included in the climatic region known as the South American Arid Diagonal covering a large part of the subcontinent from northern Peru along the Andes to the south of Neuquén continuing across Patagonia to the Chubut River (Bruniard 1982). The east band of the Payunia region is exposed to the action of the Atlantic anticyclone. However, the great distance traveled by the humid Atlantic winds results in low summer precipitation $(\sim 200 \mathrm{~mm})$. The vegetation is characterized by xerophytic shrubs, such as Prosopis torcuata, $P$. alpataco, Cercidium praecox, Chuquiraga erinacea, Cassia aphylla, Larrea, Bulnesia, and Plectrocarpa, and isolated stands of Geophroea decorticans that grow in low organic matter sandy or rocky soils (Abrahan et al. 2009; Cabrera 1976). 


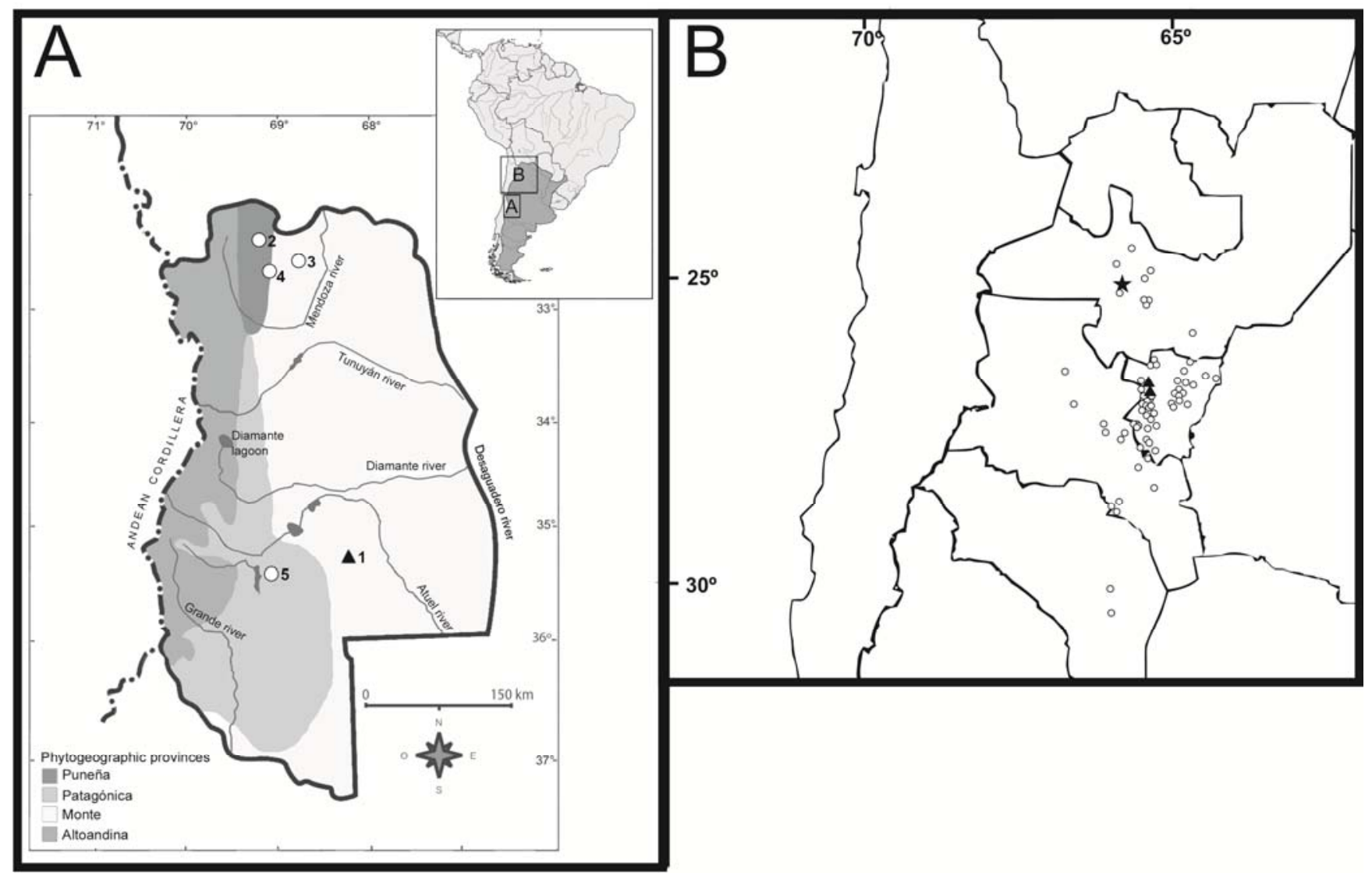

Figure 1. A: Map of Mendoza province (Argentina), recording localities for A. oenos: Triangles (archaeological) 1. Agua de La Mula (3522' S, 6815' W, 967 m above sea level). Circles (modern) 2. 2 km S of Villavicencio Ruta 32 (3231' S, 68이' W); 3. La Pega (32048' S, 6840' W, type locality); 4. Puesto de Lima (32054' S, 69001' W) and 5. Llancanelo Natural Reserve (35ㅇ' S, 69011' W). Phytogeography follows Cabrera (1976). B: Map of NW Argentina, recording localities for A. spegazzinii: star (type locality); circles (modern); triangles (fossil samples).

\section{Methods}

The Agua de La Mula site is a basaltic cave. Excavations directed by Dr. Humberto Lagiglia were done by the staff of Museo de Historia Natural de San Rafael in 1987 in 10 levels of $10 \mathrm{~cm}$ each. 1026 small mammal bones and bone fragments were recovered from levels 4, 5, 6, 7, 9, and 10, as were other organic materials such as remains of domestic plants (Zea mays and Cucurbita sp.) (LP-563, charcoal sample, level 10, $1610 \pm 60$; LP-620, charcoal sample, level 10, $1260 \pm$ 60; LP-973, charcoal sample, level 5, $1000 \pm 50 \mathrm{C}^{14} \mathrm{yr}$ B.P.). Two cranial specimens of $A$. oenos (a juvenile and an adult individual) were identified from levels 5 and $6 .{ }^{1}$ Morphological description and craniodental measurements of $A$. oenos (taken with a digital caliper to the nearest $0.01 \mathrm{~mm}$ ) were made following criteria reported by Myers (1989). These data were compared with those provided by Braun et al. (2000) and with those from a sample of ten specimens of $A$. iniscatus mucus from the
Neuquén province. ${ }^{2}$ Un-fortunately, measurements from the juvenile specimen of $A$. oenos from the site could not be taken due to its fragmentary condition.

Paleoenvironmental analysis using small mammal remains is based on modern ecological requirements and biogeographic distributions for various taxa represented in the Agua de la Mula fauna. For comparative purposes an additional study was done on the area's modern small mammals. A sample of 22 pellets of black-chested buzzard-eagle (Geranoaetus melanoleucus, Accipitridae) and trapping data were analyzed, identifying 28 individual micromammals.

\section{The Modern Small Mammal Assemblage}

The modern fauna is made up primarily of sigmodontine rodents, with Graomys griseoflavus (MNI\% 17.9), and Eligmodontia sp. (MNI\% 10.7) well represented, followed by low frequencies of Phyllotis xanthopygus (MNI\% 7.1), Calomys musculinus (MNI\% 


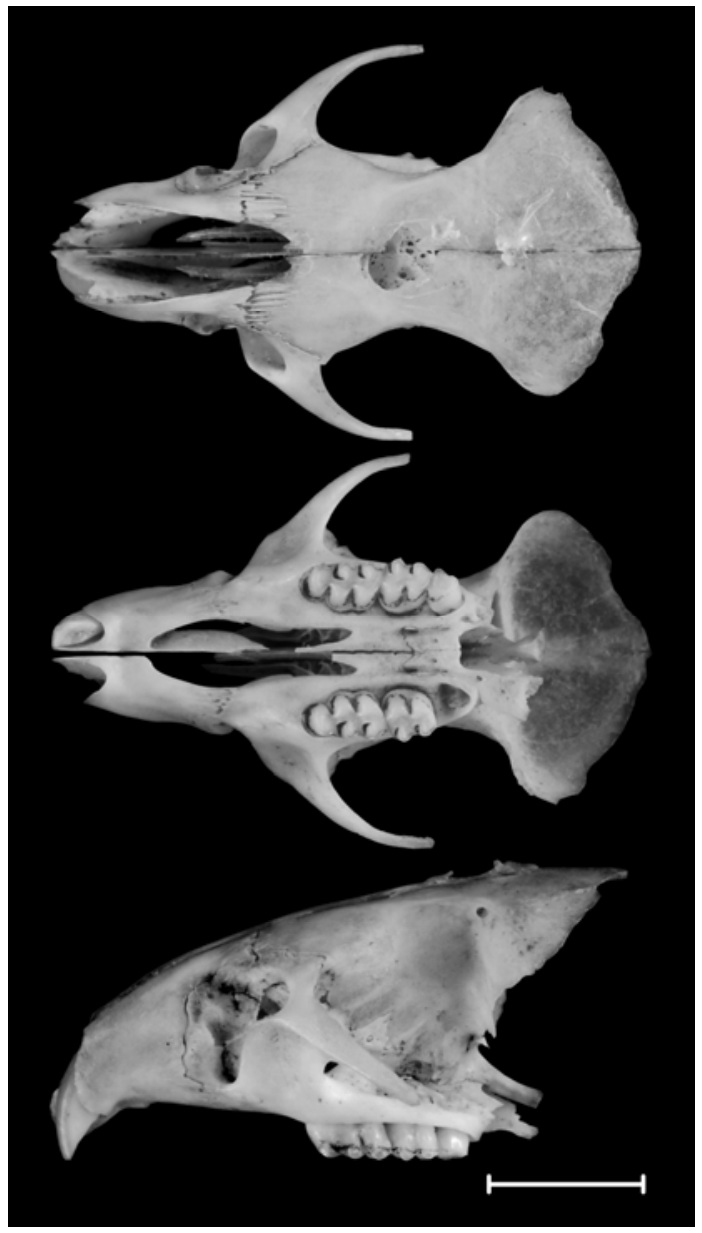

Figure 2. Dorsal, ventral and lateral views of cranium of Akodon oenos (MHNSR 15.002). Scale: $5 \mathrm{~mm}$.

7.1), and Akodon molinae (MNI\% 3.6). A single hystricognath rodent Galea leucoblephara (MNI\% 28.6) was recorded, and one chiropteran Tadarida brasiliensis (MNI\% 3.6), and one marsupial marmosine Thylamys pallidior (MNI\% 3.6). The modern small mammal assemblage also contained one exotic lagomorph (MNI\% 7.1).

\section{Small Mammals at Agua de La Mula}

A sample of 1026 cranial remains was analyzed, and represents an MNI of 491. In this assemblage, hystricognath rodents dominate, Ctenomys sp. (MNI\% 41.9), Microcavia australis (MNI\% 7.7), and $G$. leucoblephara (MNI\% 5.3), followed by remains of sigmodontine rodents, $P$. xanthopygus (MNI\% 16.1), G. griseoflavus (MNI\% 14.1), Eligmodontia sp. (MNI\% 3.1), A. molinae (MNI\% 2.2), Reitbrodon auritus (MNI\% 1), C. musculinus (MNI\% 0.4), and A. oenos (MNI\% 0.4). A single chiropteran T. brasiliensis (MNI\% 0.4 ) was recorded, as were two marsupial marmosines $T$. pallidior (MNI\% 6.3), and Lestodelphys halli (MNI\% 1).
The adult specimen of $A$. oenos is represented by a fragmented cranium that is missing the braincase (Figure 2). It is medium in size compared to other individuals in the genus with a relatively short and wide rostrum. The interorbital region is narrow and hourglass shaped with frontals that are rounded in the dorsolateral margins. The frontoparietal suture is crescent-shaped. The zygomatic notches are moderately wide and deep. The zygomatic plate is relatively broad, and its anterior margin is straight. The zygomatic arches are slender, the palatal bridge is short and narrow, and the incisive foramina extend posteriorly to the protocone of $\mathrm{M}^{1}$. The posterior palatal foramina are sligthly enlarged and are located at level of the $\mathrm{M}^{2}$; there is also a second pair of small posteropalatal pits situated at the level of $\mathrm{M}^{3}$. The mesopterygoid fossa is narrow, with an anterior border tending towards a lyre shape. Upper incisors are orthodont, and toothrows are parallel. Molars are relatively hipsodont and robust, with the major cups about equal in size.

This description agrees with that provided by Braun et al. (2000) for $A$. oenos and differs from other species in Akodon that inhabit the region, such as $A$. molinae and A. iniscatus. Akodon molinae is distinguished by its comparatively wide interorbital region, square frontals, and parallel dorsolateral margins. The zygomatic plate of $A$. molinae is wide with slightly convex edges that are oriented obliquely backwards and down; the palatal bridge is long and wide. Akodon iniscatus is characterized by a long and wide palatal bridge, a narrow zygomatic plate, extension of the incisive foramina posteriorly to the hipocone of $\mathrm{M}^{1}$, a moderately narrow mesopterygoid fossa, a slightly Mshaped anterior border, opistodont upper incisors, and slender molars. In terms of biometry, the specimen from Agua de La Mula falls within the range of $A$. oenos described by Braun et al. (2000) (Table 1).

\section{Discussion}

The taxonomic status of $A$. oenos is currently being assessed. The species was described by Braun et al. (2000) based on individuals labeled by Contreras and Rosi as "Akodon minoprioi," and as that original study was not formally published A. minoprioi, it became a nomen nudum (Galliari et al. 1996). Recent research conducted by Pardiñas et al. (2011) based on extensive morphologic and molecular data suggests that $A$. oenos is a junior synonym of $A$. spegazzinii and that it belongs to the $A$. boliviensis species group of Akodon. The geographic distribution of $A$. spegazzinii extends to $\mathrm{La}$ Rioja, Catamarca, Tucumán, and Salta provinces, with the type locality in Lower Cachi, central Salta (2507'11.93"S, 66009'47"W, $2341 \mathrm{~m}$ above sea level, 
Table 1. Descriptive statistics of craniodental measurements (in $\mathrm{mm}$ ) of the Agua de La Mula adult specimen of Akodon oenos, the $A$. oenos holotype, and individuals of $A$. molinae and $A$. iniscatus nucus.

\begin{tabular}{lccccc}
\hline & $\begin{array}{c}\text { MHNSR } \\
15.002\end{array}$ & $\begin{array}{c}\text { A. oenos Holotype } \\
\text { IADIZA-CM611* }\end{array}$ & $\begin{array}{c}\text { A. oenos } \\
\text { mean* }\end{array}$ & $\begin{array}{c}\text { A. molinae } \\
\text { mean* }^{*}\end{array}$ & $\begin{array}{c}\text { A. iniscatus nucus } \\
\text { mean }\end{array}$ \\
\hline Diastema length & 6.4 & 6.9 & $6.7 \pm 0.35$ & $6.9 \pm 0.47$ & $6.5 \pm 0.29$ \\
Palatal bridge & 3.2 & 3.6 & $3.3 \pm 0.20$ & $4.0 \pm 0.31$ & $2.6 \pm 0.21$ \\
Maxillary toothrow length & 5.0 & 4.9 & $4.8 \pm 0.19$ & $4.8 \pm 0.04$ & $4.6 \pm 0.24$ \\
Incisive foramina length & 5.9 & 5.3 & $5.8 \pm 0.37$ & $5.7 \pm 0.15$ & $6.3 \pm 0.21$ \\
Zygomatic plate breadth & 2.6 & 2.5 & $2.8 \pm 0.20$ & $3.1 \pm 0.19$ & $2.9 \pm 0.16$ \\
Mid rostral width & 4.1 & 3.9 & $4.0 \pm 0.15$ & $4.2 \pm 0.23$ & $4.2 \pm 0.20$ \\
Interorbital constriction & 4.6 & 4.6 & $4.6 \pm 0.15$ & $4.7 \pm 0.16$ & $4.5 \pm 0.15$ \\
\hline
\end{tabular}

* Data from Braun et al. (2000: 219).

Figure 1B). If this taxonomic designation is correct, $A$. spegazzinii extends its geographic distribution and ecological domain from Salta province to southern Mendoza, ranging from 400 to about $3500 \mathrm{~m}$ above sea level, inhabiting arid environments of the Patagonian steppe, the Monte desert, the Puna, and the high Andes, as well as the Yungas forests, and the semi-arid forests at the ecotone of Yungas-Chaco (see Jayat 2009; Jayat et al. 2010). In addition, many fossil remains identified as $A$. spegazzinii have been recovered from two paleontological sites in northwestern Argentina, located in deposits dating to the middle-upper Pleistocene $\left(26^{\circ} 56^{\prime} \mathrm{S}, 6^{\circ} 42^{\prime} \mathrm{W}, \mathrm{La}\right.$ Angostura, Tucumán province [Ortiz and Pardiñas 2001]) and to the Pleistocene-Holocene boundary $\left(26^{\circ} 51^{\prime} \mathrm{S}, 65^{\circ} 43^{\prime}\right.$ W, Tafi del Valle, Tucumán province [Ortiz and Jayat 2007]).

The presence of pellets preserved in stratigraphy and light digestive corrosion on some teeth and postcraneal bones recovered from Agua de La Mula site, indicate that the main accumulator agent was probably an owl (Fernández et al. 2008). Small mammals collected by owl are considered good indicators of environmental conditions (Andrews 1995). The modern association of small mammals from Agua de La Mula shows a clear predominance of species characteristic of the Monte desert and the South American Arid Diagonal (G. leucoblephara, G. griseoflavus, C. musculinus, $A$. molinae, and T. pallidior), with the addition of two general Andean Patagonian taxa $(P$. xanthopygus and Eligmodontia sp.). Also, the occurrence of $P$. xanthopygus suggests a landscape dominated by open rocky areas.

Remains of $A$. oenos from Agua de La Mula were recovered together with those of small mammal species that inhabit the area today (A. molinae, G. griseoflavus, $P$. xanthopygus, C. musculinus, G. leucoblephara and $T$. pallidior). It is interesting to note the presence at this site of $L$. halli, an endemic marsupial of the Patagonian steppe that is rare in the Monte desert of Mendoza today (Chacras de Coria, 32 $45^{\prime} \mathrm{S}, 6^{\circ} 00^{\prime} \mathrm{W}$;

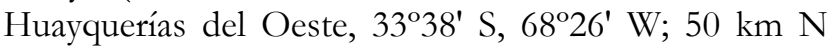

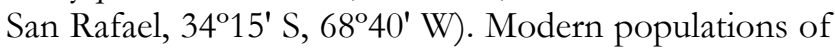
L. halli are considered relicts of those that were more widely distributed earlier in the Holocene. In addition, the occurrence of $R$. auritus suggests the development of open, herbaceous steppe environments associated with bodies of water. The presence of both species at Agua de La Mula indicates wetter and colder conditions in the past, which may have been the result of westerlies generated by the Pacific anticyclonic center (causing winter rainfall) during the late Holocene.

Palynological studies on materials from an archaeological site in the western plains of Mendoza (Gruta del Indio, 34\% $45^{\prime} \mathrm{S}, 68^{\circ} 22^{\prime} \mathrm{W}$ ), $70 \mathrm{~km}$ north of Agua de La Mula, reveal that the establishment of modern climatic conditions occured at roughly $3000 \mathrm{yr}$ B.P. (D’Antoni 1983). However, D'Antoni (1983: 97) observed a significant change in the pollen sequence between 1600 and 1200 yr B.P. when the Patagonian steppe vegetation increased (e.g., Poaceae, Cyperaceae, and Adesmia) and Monte vegetation decreased (e.g., Larrea). D'Antoni suggested that change may have resulted from selective wood exploitation by humans that inhabited this area. However, no evidence of wood exploitation in Agua de La Mula was found, and based on the small mammals analysis presented here, I propose that near Agua de La Mula between 1600 and 1000 years B.P. temperature decreased and winter precipitation increased, which produced an advance of Patagonian steppe and its associated fauna, developing 
into a transitional mosaic of Patagonian steppe and Monte desert.

Available zooarchaeological and modern data indicate that $A$. oenos are absent from Mendoza's high Andean environments. ${ }^{3}$ However, the fossil akodontine remains from Agua de $\mathrm{La}$ Mula represent an extralimital record in the palaeoenvironmental mosaic of the Patagonian-Monte during the late Holocene (Figure 1A). This species may currently be present in such environments and may be common in the unexplored volcanic Payunia region, which may be of interest to conservation scientists.

More comprehensive understanding of climatic change during the late Holocene in the region is important for the study of the late human occupation of ecologically marginal environments, such as the Payunia. Less dry and cooler environmental conditions observed at Agua de La Mula between 1600 and 1000 years B.P. probably favored human ocupation in all environments of Payunia (i.e., effective human occupation, sensu Borrero 1994-1995). Humanenvironment interactions have been discussed in archaeological literature from Mendoza (e.g., Gil 2006; Neme 2007). Available evidence suggests that economic intensification and effective occupation of Andean environments took place at 2000 yr B.P. (Neme 2007). This intensification process has been interpreted as the consequence of an imbalance between environmental carrying capacity and human population growth. Over-exploitation of the environment reduced the availability of highly-ranked resources (e.g., Lama guanicoe, Rhea americana, Pterocnemia pennata), and drove subsistence towards the inclusion of foods with lower caloric returns and higher processing costs such as some plants and small mammals (Gil 2006; Neme 2007). However, increased human occupation and economic intensification in the volcanic Payunia region occurred subsequently (about $1000 \mathrm{yr}$ B.P) and may relate to climate amelioration indicated by evidence presented here.

In summary, small mammals remains from the Agua de La Mula site in southern Mendoza strengthen understanding of the biogeography and ecology of $A$. oenos. The presence of this species in deposits that date to the late Holocene just prior to human the occupation of the Payunia during a period in which climate amelioration occurred provides insights into the conditions that promoted human occupation of the region and into the conservation biology of the species today.

\section{Acknowledgements}

I thank Ulyses Pardiñas, Cesar García-Esponda, Gustavo Neme, Pablo Teta, and Steve Wolverton for editorial comments and discussion. Gustavo Neme and Adolfo Gil provided access to the Agua de La Mula collection through the Museo de Historia Natural de San Rafael. Cesar García Esponda, Gonzalo Martinez and Fernando Ballejo assisted with preparation of the images. Germán Moreira, Fernando Ballejo, and Luciano De Santis provided assistance in the field and lab. Three anonymous reviewers provided constructive comments.

\section{References Cited}

Abraham, E., H. del Valle, F. Roig, L. Torres, J. Ares, F. Coronato, and R. Godagnone. 2009. Overview of Geography of the Monte Desert Biome (Argentina). Journal of Arid Environments 73:144-153.

Andrews, P. 1995. Mammals as Palaeoecological Indicators. Acta Zoológica Cracovensia 38:59-72.

Borrero, L. A. 1994-1995. Arqueología de la Patagonia. Palimpsesto 4:9-56.

Braun, J. K., M. A. Mares and R. A. Ojeda. 2000. A New Species of Grass Mouse, Genus Akodon (Muridae: Sigmodontinae), from Mendoza Province, Argentina. Zeitschrift für Sängetierkunde 65:216-225.

Bruniard, E. 1982. La Diagonal Árida Argentina: Un Límite Climático Real. Revista Geográfica 95:5-20.

Cabrera, A. L. 1976. Regiones Fitogeográficas Argentinas. Enciclopedia Argentina de Agricultura y Jardinería 1:1-85.

Contreras, J. F. and M. I. Rosi. 1980. Comportamiento Territorial y Fidelidad al Hábitat en una Población de Roedores del Centro de la Provincia de Mendoza. Ecología Argentina 5:17-29.

D’Antoni, H. 1983. Pollen Analysis of Gruta del Indio. Quaternary of South America and Antartic Peninsula 1:83104.

Fernández, F. J., G. J. Moreira, and L. J. M. De Santis. 2008. Análisis Preliminar del Ensamble de Micromamíferos del Sitio Arqueológico "Agua de La Mula" (Mendoza, Argentina). Paper presented at the First Congreso Nacional de Zooarqueología Argentina, Malargüe, Mendoza.

Galliari, C. A., U. F. J. Pardiñas, and F. J. Goin. 1996. Lista Comentada de los Mamíferos Argentinos. Mastozoología Neotropical 3:39-61. 
Gil, A. F. 2006. Arqueología de La Payunia (Mendoza, Argentina). El poblamiento bumano en los márgenes de la agricultura. BAR Internacional Series 1591, Oxford.

Jayat, J. P. 2009. Roedores Sigmodontinos de los Pastizales de Neblina de las Yungas de Argentina. Ph.D. Dissertation (Paleontology). Universidad Nacional de Tucumán, Tucumán.

Jayat, J. P., P. E. Ortiz, J. Salazar-Bravo, U. F. J. Pardiñas, and G. D'Elía. 2010. The Akodon boliviensis Species Group (Rodentia: Cricetidae: Sigmodontinae) in Argentina: Species Limits and Distribution, With the Description of a New Entity. Zootaxa 2409:1-61.

Myers, P. 1989. A Preliminary Revision of the Varius Group of Akodon (A. dayi, dolores, molinae, neocenus, simulator, toba and varius). In Advances in Neotropical Mammalogy, eds. K. H. Redford and J. F. Eisenberg, pp. 5-54. Sandhill Crane Press, Florida.

Neme, G. 2007. Cazadores Recolectores de Altura en los Andes Meridionales. BAR Series 1591, Oxford.

Ortiz, P. E. and U. F. J. Pardiñas. 2001. Sigmodontinos (Mammalia, Rodentia) del Pleistoceno Tardío del Valle de Tafí (Tucumán, Argentina): Taxonomía, Tafonomía y Reconstrucción Paleoambiental. Ameghiniana 38:3-26.

Ortiz, P. E. and P. Jayat. 2007. Sigmodontinos

(Rodentia: Cricetidae) del Límite Pleistoceno-Holoceno en el Valle del Tafí (Tucumán, Argentina): Taxonomía, Tafonomía y Significación Paleoambiental. Ameghiniana 44:641-660.

Pardiñas, U. F. J., P. Teta, G. D’Elía, and G. B. Diaz. 2011. Taxonomic Status of Akodon oenos (Rodentia, Sigmodontinae), An Obscure Species from West Central Argentina. Zootaxa 2749:47-61.

\section{Biosketch}

Fernando Fernández is a professor of Zooarchaeology on the Facultad de Ciencias Naturales y Museo (UNLP) in La Plata, Argentina. He is an advanced doctoral student funded by CONICET at the same university and has produced more than 30 publications and conference presentations on taphonomy, zooarchaeology, and zoogeography of microvertebrates.

\footnotetext{
${ }^{1}$ The remains were accessioned to the archaeological
} collection of Museo de Historia Natural de San Rafael as MHNSR 15.002 (adult specimen) and MHNSR 15.003 (juvenile specimen).

2 The modern specimens of Akodon iniscatus nucus are housed in the Colección de Egagrópilas y Afines "Elio Massoia" of the Centro Nacional Patagónico (Puerto Madryn, Chubut, Argentina) under the number CNP-E 88 (owl pellet sample).

${ }^{3}$ Fernández, F. J. Microvertebrados del Holoceno de sitios arqueológicos en el sur de Mendoza (República Argentina): aspectos tafonómicos y sus implicancias en la subsistencia humana. Ph.D. Dissertation (in preparation). Facultad de Ciencias Naturales y Museo, Universidad Nacional de La Plata, La Plata. 